\title{
Student Attitudes toward STEM: The Development of Upper Elementary School and Middle/High School Student Surveys
}

\section{Malinda Faber, The Friday Institute for Educational Innovation at North Carolina State University}

Malinda Faber is a Research Associate on the Evaluation Team at the Friday Institute for Educational Innovation at North Carolina State University. Malinda works on multiple research teams, including evaluations of The Golden LEAF Foundations' STEM Initiative, North Carolina's Race to the Top STEM Initiative, and the North Carolina Department of Public Instruction's IMPACT-V Model for capacitybuilding in instructional technology.

\section{Alana Unfried, North Carolina State University}

Alana Unfried is a Graduate Research Assistant at the Friday Institute for Educational Innovation at North Carolina State University. She works on the Data Analytics team for the MISO Project (Maximizing the Impact of STEM Outreach through Data-Driven Decision Making), funded by the National Science Foundation. Alana's responsibilities include the development of statistically sound evaluation instruments for teachers and students involved in these campus outreach programs. She also analyzes survey results and related data to understand the collective impact of these pre-college outreach programs. Alana is also a full-time Ph.D. student in the Department of Statistics at North Carolina State University.

\section{Dr. Eric N. Wiebe, North Carolina State University}

Dr. Wiebe is a Professor in the Department of STEM Education at NC State University and Senior Research Fellow at the Friday Institute for Educational Innovation. A focus of his research and outreach work has been the integration of multimedia and multimodal teaching and learning approaches in STEM instruction. He has also worked on research and evaluation of technology integration in instructional settings in both secondary and post-secondary education. Dr. Wiebe has been a member of ASEE since 1989.

\section{Jeni Corn, Friday Institute for Educational Innovation, NC State University}

As the Director of Evaluation Programs at the Friday Institute for Educational Innovation at NC State University, Dr. Corn serves as PI of several large, statewide evaluation and research studies of innovations in K-12 schools and districts, including leading the evaluation of initiatives funded under North Carolina's Race to the Top grant. Her research interests focus on leadership, professional development, teaching and learning, infrastructure, and evaluation for technology-enhanced innovations in public school settings.

\section{LaTricia Walker Townsend}

\section{Mrs. Tracey Louise Collins, North Carolina State University}

Tracey Louise Collins is the Project Coordinator for the MISO Project. Responsibilities include implementing activities of the project, coordinating efforts among K-12 science, technology, engineering, and mathematics (STEM) outreach programs, and working closely with university enrollment management and data management professionals at the Friday Institute at NC State University. She works closely with both large and small NC State outreach groups offering K-12 outreach to teachers and students. She also assists with planning, implementing, managing, and reporting of project activities which include survey development, coordination of data collection, interfacing with data managers, coordination of meetings and workshops for outreach providers to gather feedback, identify best practices, and disseminate findings to stakeholders. In addition, she assists with annual report writing and conference presentations. She has been a member of the American Society of Engineering Educators since 2011. 


\title{
Student Attitudes toward STEM: The Development of Upper Elementary School and Middle/High School Student Surveys
}

\begin{abstract}
The national economy is in need of more engineers and skilled workers in science, technology, and mathematics (STEM) fields who also possess competencies in critical-thinking, communication, and collaboration - also known as 21 st century skills. In response to this need, educational organizations across the country are implementing innovative STEM education programs designed in part to increase student attitudes toward STEM subjects and careers. This paper describes how a team of researchers at The Friday Institute for Educational Innovation at North Carolina State University developed the Upper Elementary School and Middle/High School Student Attitudes toward STEM (S-STEM) Surveys to measure those attitudes. The surveys each consist of four, validated constructs which use Likert-scale items to measure student attitudes toward science, mathematics, engineering and technology, 21st century skills. The surveys also contain a comprehensive section measuring student interest in STEM careers. The surveys have been administered to over 10,000 fourth through twelfth grade students in North Carolina who are participating in a variety of traditional classroom-based, elective, or informal STEM education programs. In the paper the authors explain the survey development and validation process. The report also summarizes baseline findings about student attitudes toward STEM subjects, careers, and 21st century skills, demonstrating how this survey can be a useful tool for innovative STEM education and workforce development programs.
\end{abstract}

\section{Introduction}

Discoveries in engineering, science, and technology fields drove huge advancements in human society in the 20th century, and experts anticipate a similar trend in the coming decades. ${ }^{1}$ Researchers and economists predict accelerating job-growth in these fields as well. For example, the United States Department of Commerce has already found that in the first decade of the 21st century the number of employment opportunities in these areas grew at a rate three times faster than in other fields. ${ }^{2}$ These new jobs will continue to require employees with knowledge and abilities in science, technology, engineering, and mathematics (STEM) and with an advanced set of general skills in critical-thinking, communication, and collaboration - often referred to as "21 st century skills." 3 While a small percentage of these future positions will be highly specialized and demand workers with graduate-level training, a much larger percentage will require workers with mid-level skills and STEM-related competencies. ${ }^{4,5,6}$ These jobs include positions such as electricians, dental hygienists, advanced manufacturing technicians, and construction managers. The increase in the demand for these workers is motivating K-12 schools, community colleges, and universities to increase their number of graduates with competencies in STEM and 21st century skills.

Also motivating K-12 schools, community colleges, and universities to implement new STEM and 21st century skills programs is the fact that students in the United States have been performing below those from other countries. The United States remains a world leader in discovery and innovation today, but the country is showing signs of weakness. Results from the 2006 Program for International Student Assessment (PISA) showed that 15-year-old students in 
the United States ranked 24th out of 30 Organization for Economic Cooperation and Development (OECD) countries in science literacy. ${ }^{7}$ The results also showed that the students ranked 25th in mathematics literacy. Similarly, as measured on the 2007 Trends in International Mathematics and Science Study (TIMSS), only $10 \%$ of eighth-graders in the United States performed at or above the advanced international science benchmark. ${ }^{8}$ Finally, results from the United States' 2011 National Assessment of Educational Progress (NAEP) indicated that $73 \%$ of students were not proficient in mathematics when they completed the eighth grade. ${ }^{9}$ In addition to these academic performance results, industries report challenges finding qualified workers with STEM-related skills. Hundreds of thousands of jobs remain unfilled today, even with the high rates of unemployment. ${ }^{5}$

These dramatic economic and educational trends have inspired a surge in investments in STEM education and 21st century skill-development across the United States; education researchers, program evaluators, and others have correspondingly begun developing new tools and methods to measure the impacts of these myriad programs. One such critical impact, and the impetus for the research described in the rest of this paper, is the initial effect that these programs are having on student attitudes towards STEM subject-areas. K-12 and postsecondary students lack interest in STEM relative to the societal and labor market demands. For example, many high school and postsecondary students divert from STEM pathways and occupations into other fields. More than three out of four high school students who test in the top mathematics quartile do not pursue a STEM major in college. ${ }^{4}$ Additionally, of those who pursue STEM majors, only $50 \%$ actually complete their degree in a STEM area. ${ }^{4}$ In 2011 the National Research Council called on educators to increase the number of students pursuing STEM career pathways after high school, including students from groups traditionally underrepresented in STEM-students of color, women, and students from low socioeconomic backgrounds. ${ }^{10}$ Experts on the President's Committee of Advisors on Science and Technology contend that improving the overall interest and attitude toward STEM among young students is as important as increasing the overall level of academic proficiency in STEM. ${ }^{11}$

This paper reports on the development of instruments for measuring these student attitudes towards STEM subjects, STEM career pathways, and 21st century skills among K-12 studentskey outcomes for STEM education and workforce development programs. While a few survey instruments do measure related attitudinal dimensions, they do not systematically gather this data for young students across all of the STEM subject areas. ${ }^{12}$ To contribute to efforts to meet this need for measurement tools, in 2011 and 2012 a research team at The Friday Institute for Educational Innovation at North Carolina State University developed two surveys measuring 4th through 12th grade student attitudes toward STEM subjects, toward 21st century skills, and toward STEM careers. This paper describes the instrument development process and summarizes some baseline findings. The report is divided into four sections and a conclusion. (The Upper Elementary School and Middle/High School Student Attitudes toward STEM Surveys can be found in the appendix.)

\section{Development of the pilot student attitudes toward STEM survey}

To develop the instruments measuring student attitudes toward STEM subjects, 21st century skills, and STEM careers the authors used funding from two projects. (See Figure 1 for a 
summary of the survey development process.) The first, supported by the National Science Foundation (NSF), works with university-based K-12 STEM education outreach programs both to support collaboration between the programs and to build program evaluation capacity within them. ${ }^{13}$ The other project, supported by a large, public, state-level foundation, aims to understand the impact of 14 school-based K-12 STEM education programs. ${ }^{14}$ The authors conducted a literature review, searching for instruments measuring student attitudes toward STEM, interest in STEM careers, and attitudes toward 21 st century skills. While the review revealed some instruments and tools related to the topic, the search did not reveal a complete instrument which measured student attitudes and interest to the level of specificity needed for both projects.

The research team did find one survey that sought to measure a similar set of student attitudes and interests, and used portions of this instrument. This 47-item survey had been developed by researchers to evaluate a Boston-area engineering program for middle school girls. ${ }^{15}$ It is designed to measure student attitudes toward STEM and interest in STEM-related careers, and it consists of three scales: attitudes toward engineering (12 items), attitudes toward math (13 items), and attitudes toward science (10 items). Even though the constructs did not specifically identify "technology," the fourth subject area in STEM, the authors considered the measurement of student technology-attitudes to be implicit within the attitudes toward engineering, math, and science scales. The original survey's authors reported the alpha coefficient for the attitudes toward engineering scale as above 0.80 , and for the math and science scales they reported the alpha coefficients as above 0.85 . All three factors use a five-point Likert scale for the response scale $(1=$ strongly disagree to $5=$ strongly agree). The survey includes items such as, "I can get good grades in math" and "I'll need science for my future work." The instrument also contains a section of 12 items which name STEM careers and ask students to identify their interest levels. The research team selected the three attitudes scales for engineering, mathematics, and science to use in the "Pilot Student Attitudes toward STEM Survey."

To create an instrument that more fully met the NSF outreach project and 14-grant STEM initiative evaluation goals, the authors added a fourth scale measuring student attitudes toward 21 st century skills. They adapted the scale from a comprehensive student learning conditions survey commissioned by the governor of North Carolina and developed by the Friday Institute in 2010. ${ }^{16}$ This 38 -item instrument is designed to measure the extent to which schools provide a safe, caring, engaging, 21st century learning environment for students. The instrument consists of six scales, one of which is a seven-item scale measuring 21 st century skills. This construct uses a four-point agreement scale $(1=$ strongly disagree to $4=$ strongly agree $)$ and includes items such as "In school, I am able to work well with other students in small groups" and "In school, I respect the differences among my peers." The research team used the seven items from this scale and nine items from the Friday Institute's original pilot 21 st century skills scale to create a new scale specifically measuring attitudes towards 21 st century skills. The evaluators modified the items to measure attitudes by replacing the original stem, "In school I," with "I am confident I can." For example, "In school I respect the differences among my peers" became "I am confident I can respect the differences among my peers." Additionally, the researchers adapted the response scale to align with the engineering, math, and science factors, replacing the four-point agreement scale with a five-point scale. 
Finally, the research team added a "Your Future" section to the survey to measure student interest in STEM career pathways. Starting with the list of 12 STEM careers in the Boston-area engineering program survey, and using the Bureau of Labor Statistics' Occupational Outlook Handbook, ${ }^{17}$ the authors crafted a more robust list of 43 STEM occupations. This list included jobs such as Animal Scientists, Biomedical Engineers, Computer Support Specialists, Epidemiologists, and Physicians and Surgeons. To assist any students not already familiar with the career, each item provided a brief description of the occupation, such as "Epidemiologists investigate and describe the causes and spread of disease, and develop the means for prevention or control," and "Agricultural engineers design agricultural machinery, equipment, sensors, processes, and structures, such as those used for crop storage. They develop ways to conserve soil and water and to improve the processing of agricultural products." The section used a fourpoint response scale $(1=$ not at all interested to $4=$ very interested $)$.

To collect additional information about the students participating in the outreach project and the STEM initiative, the research team added a brief "About Yourself" section to the end of the Pilot Student Attitudes toward STEM Survey. Also adapted from the Boston-area engineering survey, this section asked students to self-report how well they think they will do in their English, mathematics, and science classes, to share whether or not they plan to attend college, and to indicate whether or not they know any engineers, scientists, or mathematicians. In its final form, therefore, the pilot student survey included: four sections measuring student attitudes toward science, mathematics, engineering, and $21^{\text {st }}$ century skills; a section measuring student interest in STEM careers; and a section collecting some background information about the students.

\section{Pilot survey administration and first edits}

The research team administered the Pilot Student Attitudes toward STEM Survey to one hundred nine 6th through 12th graders who were participating in various programs within the NSF-funded outreach project. A majority of those university outreach programs were elective programs that were taking place afterschool or during the summer. Some of them served students from groups traditionally underrepresented in STEM fields, and others had no specific, target participants. Regardless of the population, since these were elective programs, the authors took into account that some self-selection bias was likely impacting results from this administration. Additional exploratory and confirmatory analyses were later conducted with data collected from a second, much larger administration to other students, a majority of whom were participating in traditional, classroom-based programs. (This is described further below.)

After collecting the data from the outreach programs, the authors used exploratory factor analysis to assess construct validity based on the pilot responses. In the analysis the team used principal axis factoring and promax rotation to allow factors to be correlated, and the researchers classified item loadings above 0.40 as significant. Items with two or more loadings above 0.30 were considered to be cross-loading. The team used the Kaiser Criterion as well as scree plots and interpretability to select the number of factors. The evaluators also used factor analysis on each independent section of the survey. For instance, factor analysis was used separately on the engineering attitudes section and on the math attitudes section. The researchers also used factor analysis on all the attitudes questions taken as a whole (the attitudes toward science, math, engineering, and 21 st century skills) with the hope that the results would indicate that each 
survey section does act as a single construct. Finally, factor analysis was conducted on the 43item career section to determine how students tended to group careers based upon interest. In that way each factor revealed by the analysis defined a group of careers that were similar.

In the next analysis phase the authors assessed content validity of the 6th through 12th grade survey through the use of subject matter experts. Three subject matter experts rated items in the four attitudes toward science, engineering, math, and 21 st century skills scales as "Essential," "Useful but not Essential," or "Not Necessary." Using the collected data, the researchers calculated Lawshe's content validity ratio (CVR) for each item. Ranging from negative one to positive one, a positive CVR indicates that over half of the subject matter experts rated the item as "Essential." Within the attitudes toward engineering scale, items that were specific (e.g. "At the science museum, I like the exhibit on robotics") tended to have a lower CVR than items that were more generic (e.g. "Engineering skills will allow me to improve society"). The attitudes toward math, science, and 21 st century skills constructs received positive ratings overall.

Based on results from construct and content validity analyses, the team made a variety of changes to the pilot attitudes toward math, science, and 21 st century skills constructs. The researchers dropped seven questions total from the math, science, and 21 st century learning sections and slightly reworded others. To reduce potential confusion on the part of respondents, the researchers also removed negative wording from items, changing phrases like "I am not interested..." to "I am interested..." These changes resulted in revised constructs with ten attitudes toward math items, nine attitudes toward science items, and thirteen attitudes toward 21 st century skills items.

Also based on the results from the factor analysis and the review of subject matter experts the authors found that the engineering construct needed to be adjusted. Even though the original creators of the Boston-area engineering survey found that the attitudes toward engineering construct was reliable, with an alpha coefficient of 0.80 , the research team found that the construct did not perform as strongly under validity testing. The authors, therefore, collaborated with engineering education experts at North Carolina State University and completed significant revisions to the attitudes toward engineering section. Removing gender-biased items was one key objective of this process. For example, an original pilot item read, "I would like to learn how to make safer cosmetics." The engineering education experts and researchers did not find this item to be gender neutral and removed it from the construct. They also aimed to make the engineering attitudes section a more comprehensive measure by including items relevant to engineering careers requiring a Bachelor's degree as well as those not requiring a Bachelor's degree, like technologists. The team developed new questions to include words like "design," "create," and "imagine" as well as words like "build" and "fix." They renamed the engineering section "Engineering and Technology" to reflect the new focus on the work of not only engineers but also of technologists and other skilled workers. It was decided that the work of technologists and engineers is interconnected and interchangeable enough that the survey validity would increase more by placing these items in a single construct, instead of in two separate constructs. The revised engineering and technology construct contained 11 items.

Finally, the authors edited the careers section based on factor analysis results, expert feedback, participant feedback, and additional literature review. The team edited the original 43 career 
items down to 12 STEM career pathways, each of which represents various possible STEM occupations. For example, the pilot instrument listed the careers of epidemiologist, medical scientist, and biomedical engineer, and the team merged these into a general "medical science" career pathway. (It is interesting to note that the factor analysis indicated some specific engineering careers, such as biomedical engineer, did not group with the general engineering career area.) These 12 revised career-pathway items each contained a brief definition of the pathway and gave examples of occupations. For instance "Medical Science" used the description "Medical science involves researching human disease and working to find new solutions to human health problems" and listed the specific career examples: "clinical laboratory technologist, medical scientist, biomedical engineer, epidemiologist, and pharmacologist." Three of these careers were unique items in the original, pilot survey. The authors were careful to ensure that job titles included both careers that would require four-year or advanced college degrees and careers that would not. Even though some national organizations do not identify the health professions as STEM careers, the researchers chose to write an item measuring student interest in "Medicine." This career pathway described the work of physicians, nurses, etc.

As these edits were being made to the pilot 6th through 12th grade survey, now called the "Middle/High School Student Attitudes toward STEM Survey," the authors developed a version of the survey for 4th through 5th grade student students. Using the original Pilot Student Attitudes toward STEM Survey (without the edits to the engineering section, the removal of negative wording, or the dropped questions), the research team slightly altered each question to use language that might be more familiar to fourth- and fifth-grade students. For example, "I am confident I can include others' perspectives when making decisions" was re-written to read, "When I make decisions, I think about what is good for other people." The evaluators edited the careers section by simplifying the descriptions of each career pathway and removing the lists of sample occupations.

Two subject matter experts reviewed the attitudes toward science, engineering, math, and $21 \mathrm{st}$ century learning scales in this first draft of the pilot 4th through 5th grade student survey. They rated each item as "Essential," "Useful but not Essential," or "Not Necessary," and the research team then calculated Lawshe's content validity ratio for each survey item. The experts' responses were similar to the responses of the experts who reviewed the items at the 6th through 12th grade reading level. The engineering questions that measured specific attitudes received lower ratings than more generic engineering questions, and the science, math, and 21 st century learning scales were rated positively overall. These CVR results and those from the experts' responses to the 6th through 12th grade survey were considered together in future edits to the surveys.

In the next phase of editing, the authors made the same revisions to the pilot 4th through 5th grade survey that had been made to the middle/high school student survey, including removing negative wording, removing gender bias from the engineering section, adding items to measure technical skills, and dropping some math and science items. In this way the second draft of the pilot upper elementary school survey exactly paralleled the middle/high school student survey. The evaluators then conducted cognitive interviews with five 5th grade students to gain their assistance in the further re-wording of the items. The students gave input as to which words were too complicated for them or their peers and what questions were confusing. 
Figure 1. S-STEM development process

\begin{tabular}{|c|}
\hline Existing Items \\
- Women in Engineering Program Survey - Boston, MA \\
O Science, engineering and mathematics attitude items \\
$\circ \quad$ STEM career interest items \\
○ "About Yourself" items \\
- NCSU Student Learning Conditions Survey - Raleigh, NC \\
O 21st century skills items
\end{tabular}

\section{Pilot Student Attitudes toward STEM Survey}

Pilot administration of survey to 109 students

Initial Construct and content validity assessment

Revise each construct of Pilot Attitudes toward STEM Survey

- $\quad$ STEM attitude items revised or dropped

- 21st century items revised

- $\quad$ STEM career items edited down from 43 to 12

\section{Middle/High School Student Attitudes toward STEM Survey}

Use the Middle/High School Student Attitudes Survey (S-STEM) to create a version for upper elementary grades (4-5th)

Cognitive interviews with fifth-graders to further refine upper elementary

\section{Upper Elementary School Student Attitudes toward STEM Survey}

Administer Middle/High S-STEM to 9,081 6-12th grade students

Administer Upper Elementary S-STEM to 799 4-5th grade students

- Assess construct validity

- Calculate reliability of each construct

- Revise to retain parallelism of instruments

- Assess reading level

- Analyze function with gender groups

Middle/High \& Upper Elementary S-STEM development complete 


\section{Second survey administration and final edits}

In the fall and winter of 2011 and 2012 the authors administered the revised Middle/High School Student Attitudes toward STEM Survey (Middle/High S-STEM) and "Upper Elementary School Student Attitudes toward STEM Survey" (Upper Elementary S-STEM) to students participating in the 14-grant STEM initiative. A total of 9,081 sixth through twelfth grade students and 799 fourth through fifth grade students responded to the surveys. Ten out of these fourteen grants were implementing programs in regular, non-elective STEM courses in K-12 schools. Students participating in these 10 grants constituted approximately $88 \%$ of the total number surveyed, thus reducing the level of selection bias likely present in earlier data sets.

The authors used exploratory factor analysis again to assess construct validity based on the responses to the revised Middle/High S-STEM and the new Upper Elementary S-STEM. The researchers used the same methods and cutoffs as the pilot analysis. Also like the pilot revisions, the team conducted factor analysis on the scales individually as well as on all attitudes questions as a whole. The authors analyzed both surveys separately, but if the team decided to drop items from one survey, then they also dropped these items from the other. In this way the Middle/High S-STEM and the Upper Elementary S-STEM remained parallel and would seek to measure the constructs in the same way.

For the Middle/High S-STEM, when all attitudes questions were analyzed as a whole, the researchers found a clear factor structure. Almost all items loaded significantly on their expected constructs. Two math items and one science item did not load at the 0.40 level on any construct, although they did load at the highest level on their expected constructs. No items cross-loaded. When examining the Upper Elementary S-STEM results the research team also found a clear structure with no cross-loading. Three math attitudes questions and one science attitude question, however, did not load significantly on any factor. These were the same questions that did not load in the Middle/High S-STEM, plus one extra math question. Taking into account the factor analysis results, the results from subject matter expert feedback, the cognitive interviews with fifth-graders, and literature reviews, the authors decided to drop from both surveys the two math questions that did not load significantly on either survey. Two science attitudes items and two attitudes toward 21st century learning items were also dropped to shorten the overall survey lengths. Due to the clear structure of the factor analysis results, the authors made no additional wording or survey changes.

In a final phase of analysis the author team examined the appropriateness of the surveys for the reading levels of the student respondents using differential item functioning and teacher feedback. Teachers rated each student survey question as either "Too Easy (below grade level)," "Just Right (at grade level)," or "Too Hard (above grade level)." Seven middle and high school teachers and ten upper elementary school teachers uniformly indicated that their respective surveys were at an appropriate length and difficulty for their students. Differential item functioning results indicated that students at different grade levels comprehend the surveys in a similar manner. Measurement invariance held at all five levels. These results indicated that the surveys were written at an appropriate level for the intended respondents.

Similarly, the authors analyzed gender groups using differential item functioning. Measurement invariance held at the first three, most essential levels. Lack of factor covariance invariance indicated that males and females view the relationships between STEM subjects differently. For instance, 
females view the relationship between math and science differently than males. This did not indicate a problem with the way the surveys were written, rather it suggested an interesting difference in the way male students and female students view STEM subjects and careers.

\section{Initial findings from surveys}

The finalized Upper Elementary S-STEM and Middle/High S-STEM survey instruments continue to serve as useful tools in the evaluations of the university's outreach projects and the 14-grant K-12 STEM initiative. Results from the winter 2012 administration to the students participating in the K-12 STEM initiative revealed some interesting baseline findings. For example, survey data indicated that students overall had only moderately positive attitudes toward science, mathematics, and engineering and technology. Variation in attitudes between students at different school-levels was very slight, with mean composite scores for each of the three factors ranging only from 3.3 (ninth through twelfth grade students' attitudes toward engineering and technology) to 3.7 (fourth through fifth grade students' attitudes toward mathematics). On average, upper elementary school students had only slightly higher mean composite scores for all three factors as compared to middle and high school students. Additionally, findings from the surveys suggested that all students were most favorable toward 21 st century learning skills (4.0 mean composite score for all students combined) as compared to their combined attitudes toward math, science, or engineering and technology (3.6, 3.4, and 3.4).

Results from the survey administration showed that students had generally moderate interest in STEM careers. The greatest proportion of students indicated that they were "interested" or "very interested" in veterinary work (51.4\%), while the smallest proportion of students reported that they were "interested" or "very interested" in careers in physics $(29.8 \%)$. On average female and male students expressed a similar level of interest in STEM careers as a whole $(42.6 \%$ and $38.9 \%$ on average). When STEM career pathways were analyzed separately, however, female students had particularly low levels of interest in engineering, computer science, energy, and physics. For those four career pathways female students had interest levels lower than a 30\% proportion "interested/very interested," while there was not a single STEM field for which male students expressed interest levels lower than a 30\% proportion. The differences in levels of interest in STEM careers between students of different races/ethnicities were smaller than the differences between male and female students. Asian students had the highest average level of interest in STEM careers (47.0\%) and White/Caucasian students and Black/African American students had the lowest average levels (39.8\% and $40.0 \%$ respectively). Of the 14 school-based STEM education grants, approximately $50 \%$ of the programs have used results from the surveys in strategic planning, presentations to boards, in independent survey administrations, or in formal professional development sessions with staff. The three largest university STEM outreach programs and the statewide Science Olympiad program have committed to using the surveys and results in their internal program evaluation and continuous improvement processes.

\section{Conclusion}

The university's outreach project and the state foundation's14-grant K-12 STEM initiative explicitly aim to improve young people's attitudes toward STEM and their interest in STEM career pathways, with the ultimate goal of increasing student learning and employability in STEM. A national surge in 
STEM education programs is taking place. This is partly in response to powerful, societal trends indicating an increase in the need for workers with STEM and 21st century skills and a simultaneous decrease in the STEM competencies and 21st century skills of United States students relative to students from other countries. Noting the limited number of valid, reliable surveys available to measure students' attitudes toward STEM, a key outcome for these education programs, the authors developed the Upper Elementary and Middle/High S-STEM surveys. These instruments can serve as valuable tools for schools, organizations, researchers, and evaluators in STEM education and workforce development programs across the nation.

The process described in this paper demonstrates that the Upper Elementary and Middle/High SSTEM Surveys are valid and reliable instruments. The researchers found that both surveys have four, clear constructs measuring student attitudes toward science, math, engineering and technology, and 21 st century skills. These constructs can help measure the impact of various interventions on student interest and confidence in STEM subjects, including programs that implement new curricula, use new instructional strategies, or provide new learning opportunities. The science construct consists of nine items; the math construct consists of eight items; and the engineering and technology construct and 21st century skills construct both consist of eleven items. The authors calculated reliability levels for the four constructs to be above 0.83 . Both surveys also have a comprehensive section measuring student career interests. The items in this construct can help schools, organizations, or researchers determine the degree to which a program has influenced student-interest in 12 STEM career pathways ranging from physics to medicine.

The need for a nationwide effort to transform STEM teaching and learning in K-12 education is clear. Many advances in society will continue to come from the fields of engineering and science. United States job-growth has been accelerating in the STEM fields over the past decade or more, and researchers predict the trend will continue. American students, however, exhibit below-average knowledge and skills when compared to other OECD countries - relatively few students enter postsecondary STEM education and even fewer complete their certification or degree. For these reasons educators, researchers, and policymakers must all work towards improving student attitudes toward STEM and increasing student knowledge and skills in these fields. Reliable, validated surveys measuring student attitudes toward STEM and 21st century skills can play a keep role in helping reach that goal.

\section{Acknowledgements}

This material is based upon work supported in part by the National Science Foundation under Grant No. (DUE-1038154). Any opinions, findings, and conclusions or recommendations expressed in this material are those of the author(s) and do not necessarily reflect the views of the National Science Foundation. Portions of the work were also supported by The Golden LEAF Foundation.

\section{References}

1. National Academy of Engineering. (2008). Grand challenges for engineering. Washington, DC: The National Academies Press. 
2. United States Department of Commerce. (2012). The Competitiveness and Innovative Capacity of the United States. Washington, DC: United States Department of Commerce.

3. Partnership for 21st Century Skills. (2004). Homepage. Retrieved March, 2006, from http://www.21stcenturyskills.org/index.php

4. Carnevale, A. P., Smith, N. \& Melton, M. (2011). STEM: Science, Technology, Engineering, Mathematics. Georgetown University Center on Education and the Workforce: Washington, DC.

5. Pathways to Prosperity Project (2011). Pathways to Prosperity: Meeting the Challenge of Preparing Young Americans for the 21 st Century. Harvard Graduate School of Education: Cambridge, MA.

6. MetLife \& Harris Interactive (2011). The MetLife Survey of the American Teacher: Preparing Students for College and Careers. Retrieved January 2, 2012 from http://www.metlife.com/assets/cao/contributions /foundation/americanteacher/MetLife_Teacher_Survey_2010.pdf

7. Baldi, S., Jin, Y., Skemer, M., Green, P.J., \& Herget, D. (2007). Highlights from PISA 2006: Performance of U.S. 15-year-old students in science and mathematics literacy in an international context (NCES 2008-016). Washington, DC: National Center for Education Statistics, Institute of Education Sciences, U.S. Department of Education.

8. Gonzales, P., Williams, T., Jocelyn, L., Roey, S., Kastberg, D., \& Brenwald, S. (2008). Highlights From TIMSS 2007: Mathematics and science achievement of U.S. fourth-and eighth-grade students in an international context (NCES 2009-001 Revised). Washington, DC: National Center for Education Statistics, Institute of Education Sciences, U.S. Department of Education.

9. National Center for Education Statistics. (2011). The Nation's Report Card: Mathematics 2011 (NCES 2012458). Washington, DC: Institute of Education Sciences, U.S. Department of Education.

10. National Research Council. (2011). Successful K-12 STEM Education: Identifying Effective Approaches in Science, Technology, Engineering, and Mathematics. Board on Science Education and Board on Testing and Assessment, Division of Behavioral and Social Sciences and Education. Washington, DC: The National Academies Press.

11. PCAST, President's Committee of Advisors on Science and Technology. (2010). Prepare and Inspire: K-12 Education in Science, Technology, Engineering, and Math (STEM) for America's Future. Washington, DC: Executive Office of the President.

12. Minner, D., Ericson, E., Wu, S., \& Martinez, A. (2012). Compendium of STEM Student Instruments PART II: Measuring Students' Content Knowledge, Reasoning Skills, and Psychological Attributes. Washington, DC: Abt Associates.

13. MISO Project. Homepage. 2012 [cited 2012 December 12]; Available from: http://miso.ncsu.edu

14. Corn, J., Faber, M., Howard, E., \& Walton, M. (2012). Golden LEAF STEM Initiative Evaluation: Descriptive Data Report. Raleigh, NC: Friday Institute for Educational Innovation, North Carolina State University. Available from http://cerenc.org

15. Erkut, S. \& Marx, F. (2005). 4 schools for WIE (Evaluation Report). Wellesley, MA: Wellesley College, Center for Research on Women. Retrieved January 2, 2012 from http://www.coe.neu.edu/Groups/stemteams /evaluation.pdf

16. The William and Ida Friday Institute for Educational Innovation. (2011). Governor Perdue's North Carolina Student Learning Conditions Survey (SLCS): Survey Implementation Study. Raleigh, NC: Author.

17. Bureau of Labor Statistics. (2011). Occupational outlook handbook (2010-11 edition). Washington, DC: U.S. Department of Labor. Retrieved January 2, 2012 from http://www.bls.gov/ooh/ 


\section{Appendix}

\section{Upper Elementary School Student Attitudes toward STEM (S-STEM) $-4-5^{\text {th }}$}

\section{Directions:}

There are lists of statements on the following pages. Please mark your answer sheets by marking how you feel about each statement. For example:

\begin{tabular}{|c|c|c|c|c|c|}
\hline Example 1: & $\begin{array}{c}\text { Strongly } \\
\text { Disagree }\end{array}$ & Disagree & $\begin{array}{c}\text { Neither } \\
\text { Agree nor } \\
\text { Disagree }\end{array}$ & Agree & $\begin{array}{c}\text { Strongly } \\
\text { Agree }\end{array}$ \\
\hline I like engineering. & 0 & 0 & 0 & 0 & 0 \\
\hline
\end{tabular}

As you read the sentence, you will know whether you agree or disagree. Fill in the circle that describes how much you agree or disagree.

Even though some statements are very similar, please answer each statement. This is not timed; work fast, but carefully.

There are no "right" or "wrong" answers! The only correct responses are those that are true for you. Whenever possible, let the things that have happened to you help you make a choice.

Please fill in on only one answer per question.

Recommended citation for this survey:

Friday Institute for Educational Innovation (2012). Upper Elementary School Student Attitudes toward STEM Survey. Raleigh, NC: Author. 
Math

\begin{tabular}{|c|c|c|c|c|c|}
\hline & $\begin{array}{l}\text { Strongly } \\
\text { Disagree }\end{array}$ & Disagree & $\begin{array}{l}\text { Neither } \\
\text { Agree nor } \\
\text { Disagree }\end{array}$ & Agree & $\begin{array}{c}\text { Strongly } \\
\text { Agree }\end{array}$ \\
\hline $\begin{array}{l}\text { 1. Math has been my worst } \\
\text { subject. }\end{array}$ & O & O & O & O & O \\
\hline $\begin{array}{l}\text { 2. I would consider choosing a } \\
\text { career that uses math. }\end{array}$ & O & 0 & 0 & O & O \\
\hline 3. Math is hard for me. & 0 & 0 & 0 & 0 & 0 \\
\hline $\begin{array}{l}\text { 4. I am the type of student to do } \\
\text { well in math. }\end{array}$ & O & 0 & 0 & O & O \\
\hline $\begin{array}{l}\text { 5. I can handle most subjects } \\
\text { well, but I cannot do a good } \\
\text { job with math. }\end{array}$ & 0 & 0 & 0 & 0 & O \\
\hline $\begin{array}{l}\text { 6. I am sure I could do advanced } \\
\text { work in math. }\end{array}$ & 0 & 0 & 0 & 0 & O \\
\hline 7. I can get good grades in math. & 0 & 0 & 0 & 0 & 0 \\
\hline 8. I am good at math. & 0 & O & O & O & 0 \\
\hline
\end{tabular}

\section{Science}

\begin{tabular}{|c|c|c|c|c|c|}
\hline & $\begin{array}{l}\text { Strongly } \\
\text { Disagree }\end{array}$ & Disagree & $\begin{array}{l}\text { Neither } \\
\text { Agree nor } \\
\text { Disagree }\end{array}$ & Agree & $\begin{array}{c}\text { Strongly } \\
\text { Agree }\end{array}$ \\
\hline $\begin{array}{l}\text { 9. I am sure of myself when I do } \\
\text { science. }\end{array}$ & 0 & 0 & 0 & 0 & 0 \\
\hline $\begin{array}{l}\text { 10. I would consider a career in } \\
\text { science. }\end{array}$ & O & 0 & O & 0 & O \\
\hline $\begin{array}{l}\text { 11. I expect to use science when I } \\
\text { get out of school. }\end{array}$ & 0 & 0 & 0 & O & 0 \\
\hline $\begin{array}{l}\text { 12. Knowing science will help } \\
\text { me earn a living. }\end{array}$ & 0 & 0 & 0 & 0 & 0 \\
\hline $\begin{array}{l}\text { 13. I will need science for my } \\
\text { future work. }\end{array}$ & 0 & 0 & 0 & 0 & 0 \\
\hline $\begin{array}{l}\text { 14. I know I can do well in } \\
\text { science. }\end{array}$ & 0 & 0 & 0 & 0 & 0 \\
\hline $\begin{array}{l}\text { 15. Science will be important to } \\
\text { me in my life's work. }\end{array}$ & 0 & 0 & 0 & 0 & O \\
\hline $\begin{array}{l}\text { 16. I can handle most subjects } \\
\text { well, but I cannot do a good } \\
\text { job with science. }\end{array}$ & 0 & 0 & 0 & 0 & 0 \\
\hline
\end{tabular}




\begin{tabular}{|l|c|c|c|c|c|}
\hline & $\begin{array}{c}\text { Strongly } \\
\text { Disagree }\end{array}$ & Disagree & $\begin{array}{c}\text { Neither } \\
\text { Agree nor } \\
\text { Disagree }\end{array}$ & Agree & $\begin{array}{c}\text { Strongly } \\
\text { Agree }\end{array}$ \\
\hline $\begin{array}{c}\text { 17. I am sure I could do advanced } \\
\text { work in science. }\end{array}$ & 0 & 0 & 0 & 0 & 0 \\
\hline
\end{tabular}

\section{Engineering and Technology}

Please read this paragraph before you answer the questions.

Engineers use math, science, and creativity to research and solve problems that improve everyone's life and to invent new products. There are many different types of engineering, such as chemical, electrical, computer, mechanical, civil, environmental, and biomedical. Engineers design and improve things like bridges, cars, fabrics, foods, and virtual reality amusement parks. Technologists implement the designs that engineers develop; they build, test, and maintain products and processes.

\begin{tabular}{|l|c|c|c|c|c|}
\hline & $\begin{array}{c}\text { Strongly } \\
\text { Disagree }\end{array}$ & Disagree & $\begin{array}{c}\text { Neither } \\
\text { Agree nor } \\
\text { Disagree }\end{array}$ & Agree & $\begin{array}{c}\text { Strongly } \\
\text { Agree }\end{array}$ \\
\hline $\begin{array}{l}\text { 18. I like to imagine creating new } \\
\text { products. }\end{array}$ & 0 & 0 & 0 & 0 & 0 \\
\hline $\begin{array}{l}\text { 19. If I learn engineering, then I } \\
\text { can improve things that } \\
\text { people use every day. }\end{array}$ & 0 & 0 & 0 & 0 & 0 \\
\hline $\begin{array}{l}\text { 20. I am good at building and } \\
\text { fixing things. }\end{array}$ & 0 & 0 & 0 & 0 & 0 \\
\hline $\begin{array}{l}\text { 21. I am interested in what makes } \\
\text { machines work. }\end{array}$ & 0 & 0 & 0 & 0 & 0 \\
\hline $\begin{array}{l}\text { 22. Designing products or } \\
\text { structures will be important } \\
\text { for my future work. }\end{array}$ & 0 & 0 & 0 & 0 & 0 \\
\hline $\begin{array}{l}\text { 23. I am curious about how } \\
\text { electronics work. }\end{array}$ & 0 & 0 & 0 & 0 & 0 \\
\hline $\begin{array}{l}\text { 24. I would like to use creativity } \\
\text { and innovation in my future } \\
\text { work. }\end{array}$ & 0 & 0 & 0 & 0 & 0 \\
\hline $\begin{array}{l}\text { 25. Knowing how to use math } \\
\text { and science together will } \\
\text { allow me to invent useful } \\
\text { things. }\end{array}$ & 0 & 0 & 0 & 0 & 0 \\
\hline $\begin{array}{l}\text { 26. I believe I can be successful } \\
\text { in a career in engineering. }\end{array}$ & 0 & 0 & 0 & 0 & 0 \\
\hline
\end{tabular}




\section{$21^{\text {st }}$ Century Skills}

\begin{tabular}{|c|c|c|c|c|c|}
\hline & $\begin{array}{c}\text { Strongly } \\
\text { Disagree }\end{array}$ & Disagree & $\begin{array}{c}\text { Neither } \\
\text { Agree nor } \\
\text { Disagree }\end{array}$ & Agree & $\begin{array}{c}\text { Strongly } \\
\text { Agree }\end{array}$ \\
\hline $\begin{array}{c}\text { 27. I am confident I can lead } \\
\text { others to accomplish a goal. }\end{array}$ & 0 & 0 & 0 & 0 & 0 \\
\hline $\begin{array}{c}\text { 28. I am confident I can encourage } \\
\text { others to do their best. }\end{array}$ & 0 & 0 & 0 & 0 & 0 \\
\hline $\begin{array}{l}\text { 29. I am confident I can produce } \\
\text { high quality work. }\end{array}$ & 0 & 0 & 0 & 0 & 0 \\
\hline $\begin{array}{l}\text { 30. I am confident I can respect the } \\
\text { differences of my peers. }\end{array}$ & 0 & 0 & 0 & 0 & 0 \\
\hline $\begin{array}{l}\text { 31. I am confident I can help my } \\
\text { peers. }\end{array}$ & 0 & 0 & 0 & 0 & 0 \\
\hline $\begin{array}{l}\text { 32. I am confident I can include } \\
\text { others' perspectives when } \\
\text { making decisions. }\end{array}$ & 0 & 0 & 0 & 0 & 0 \\
\hline $\begin{array}{l}\text { 33. I am confident I can make } \\
\text { changes when things do not go } \\
\text { as planned. }\end{array}$ & 0 & 0 & 0 & 0 & 0 \\
\hline $\begin{array}{l}\text { 34. I am confident I can set my } \\
\text { own learning goals. }\end{array}$ & 0 & 0 & 0 & 0 & 0 \\
\hline $\begin{array}{l}\text { 35. I am confident I can manage } \\
\text { my time wisely when working } \\
\text { on my own. }\end{array}$ & 0 & 0 & 0 & 0 & 0 \\
\hline $\begin{array}{l}\text { 36. When I have many } \\
\text { assignments, I can choose } \\
\text { which ones need to be done } \\
\text { first. }\end{array}$ & 0 & 0 & 0 & 0 & 0 \\
\hline $\begin{array}{l}\text { 37. I am confident I can work well } \\
\text { with students from different } \\
\text { backgrounds. }\end{array}$ & 0 & 0 & 0 & 0 \\
\hline
\end{tabular}

\section{Your Future}

Here are descriptions of subject areas that involve math, science, engineering and/or technology, and lists of jobs connected to each subject area. As you read the list below, you will know how interested you are in the subject and the jobs. Fill in the circle that relates to how interested you are. 
There are no "right" or "wrong" answers. The only correct responses are those that are true for you.

\begin{tabular}{|c|c|c|c|c|}
\hline & $\begin{array}{l}\text { Not at all } \\
\text { Interested }\end{array}$ & $\begin{array}{c}\text { Not So } \\
\text { Interested }\end{array}$ & Interested & $\begin{array}{c}\text { Very } \\
\text { Interested }\end{array}$ \\
\hline $\begin{array}{l}\text { 1. Physics: is the study of basic laws } \\
\text { governing the motion, energy, } \\
\text { structure, and interactions of matter. } \\
\text { This can include studying the nature of } \\
\text { the universe. (aviation engineer, } \\
\text { alternative energy technician, lab } \\
\text { technician, physicist, astronomer) }\end{array}$ & 0 & 0 & 0 & 0 \\
\hline $\begin{array}{l}\text { 2. Environmental Work: involves } \\
\text { learning about physical and biological } \\
\text { processes that govern nature and } \\
\text { working to improve the environment. } \\
\text { This includes finding and designing } \\
\text { solutions to problems like pollution, } \\
\text { reusing waste and recycling. (pollution } \\
\text { control analyst, environmental } \\
\text { engineer or scientist, erosion control } \\
\text { specialist, energy systems engineer and } \\
\text { maintenance technician) }\end{array}$ & 0 & 0 & 0 & 0 \\
\hline $\begin{array}{l}\text { 3. Biology and Zoology: involve the } \\
\text { study of living organisms (such as } \\
\text { plants and animals) and the processes } \\
\text { of life. This includes working with } \\
\text { farm animals and in areas like nutrition } \\
\text { and breeding. (biological technician, } \\
\text { biological scientist, plant breeder, crop } \\
\text { lab technician, animal scientist, } \\
\text { geneticist, zoologist) }\end{array}$ & 0 & 0 & 0 & 0 \\
\hline $\begin{array}{l}\text { Veterinary Work: involves the } \\
\text { science of preventing or treating } \\
\text { disease in animals. (veterinary } \\
\text { assistant, veterinarian, livestock } \\
\text { producer, animal caretaker) }\end{array}$ & 0 & 0 & 0 & O \\
\hline $\begin{array}{l}\text { 5. Mathematics: is the science of } \\
\text { numbers and their operations. It } \\
\text { involves computation, algorithms and } \\
\text { theory used to solve problems and } \\
\text { summarize data. (accountant, applied } \\
\text { mathematician, economist, financial } \\
\text { analyst, mathematician, statistician, } \\
\text { market researcher, stock market } \\
\text { analyst) }\end{array}$ & 0 & 0 & 0 & 0 \\
\hline
\end{tabular}




\begin{tabular}{|c|c|c|c|c|}
\hline & $\begin{array}{l}\text { Not at all } \\
\text { Interested }\end{array}$ & $\begin{array}{c}\text { Not So } \\
\text { Interested }\end{array}$ & Interested & $\begin{array}{c}\text { Very } \\
\text { Interested }\end{array}$ \\
\hline $\begin{array}{l}\text { 6. Medicine: involves maintaining health } \\
\text { and preventing and treating disease. } \\
\text { (physician's assistant, nurse, doctor, } \\
\text { nutritionist, emergency medical } \\
\text { technician, physical therapist, dentist) }\end{array}$ & 0 & 0 & 0 & 0 \\
\hline $\begin{array}{l}\text { 7. Earth Science: is the study of earth, } \\
\text { including the air, land, and ocean. } \\
\text { (geologist, weather forecaster, } \\
\text { archaeologist, geoscientist) }\end{array}$ & 0 & 0 & 0 & 0 \\
\hline $\begin{array}{l}\text { 8. Computer Science: consists of the } \\
\text { development and testing of computer } \\
\text { systems, designing new programs and } \\
\text { helping others to use computers. } \\
\text { (computer support specialist, computer } \\
\text { programmer, computer and network } \\
\text { technician, gaming designer, computer } \\
\text { software engineer, information } \\
\text { technology specialist) }\end{array}$ & 0 & 0 & O & 0 \\
\hline $\begin{array}{l}\text { 9. Medical Science: involves researching } \\
\text { human disease and working to find new } \\
\text { solutions to human health problems. } \\
\text { (clinical laboratory technologist, } \\
\text { medical scientist, biomedical engineer, } \\
\text { epidemiologist, pharmacologist) }\end{array}$ & 0 & 0 & 0 & 0 \\
\hline $\begin{array}{l}\text { 10. Chemistry: uses math and experiments } \\
\text { to search for new chemicals, and to } \\
\text { study the structure of matter and how it } \\
\text { behaves. (chemical technician, chemist, } \\
\text { chemical engineer) }\end{array}$ & 0 & 0 & 0 & 0 \\
\hline $\begin{array}{l}\text { 11. Energy: involves the study and } \\
\text { generation of power, such as heat or } \\
\text { electricity. (electrician, electrical } \\
\text { engineer, heating, ventilation, and air } \\
\text { conditioning (HVAC) technician, } \\
\text { nuclear engineer, systems engineer, } \\
\text { alternative energy systems installer or } \\
\text { technician) }\end{array}$ & 0 & 0 & 0 & 0 \\
\hline
\end{tabular}




\begin{tabular}{|l|c|c|c|c|}
\hline & $\begin{array}{c}\text { Not at all } \\
\text { Interested }\end{array}$ & $\begin{array}{c}\text { Not So } \\
\text { Interested }\end{array}$ & Interested & $\begin{array}{c}\text { Very } \\
\text { Interested }\end{array}$ \\
\hline $\begin{array}{l}\text { 12. Engineering: involves designing, } \\
\text { testing, and manufacturing new } \\
\text { products (like machines, bridges, } \\
\text { buildings, and electronics) through the } \\
\text { use of math, science, and computers. } \\
\text { (civil, industrial, agricultural, } \text { or } \\
\text { mechanical engineers, welder, auto- } \\
\text { mechanic, } \text { engineering technician, } \\
\text { construction manager) }\end{array}$ & 0 & 0 & 0 & \\
\hline
\end{tabular}

\section{About Yourself}

1. How well do you expect to do this year in your:

\begin{tabular}{|l|c|c|c|}
\hline & Not Very Well & OK/Pretty Well & Very Well \\
\hline English/Language Arts Class? & $\bigcirc$ & $\bigcirc$ & $\bigcirc$ \\
\hline Math Class? & $\bigcirc$ & $\bigcirc$ & $\bigcirc$ \\
\hline Science Class? & $\bigcirc$ & $\bigcirc$ & $\bigcirc$ \\
\hline
\end{tabular}

2. More about you.

\begin{tabular}{|l|c|c|c|}
\hline & Yes & No & Not Sure \\
\hline Do you know any adults who work as scientists? & $\bigcirc$ & $\bigcirc$ & $\bigcirc$ \\
\hline Do you know any adults who work as engineers? & $\bigcirc$ & $\bigcirc$ & $\bigcirc$ \\
\hline Do you know any adults who work as mathematicians? & $\bigcirc$ & $\bigcirc$ & $\bigcirc$ \\
\hline Do you know any adults who work as technologists? & $\bigcirc$ & $\bigcirc$ & $\bigcirc$ \\
\hline
\end{tabular}


Middle/High School Student Attitudes toward STEM (S-STEM) - 6-12 $^{\text {th }}$

Directions:

There are lists of statements on the following pages. Please mark your answer sheets by marking how you feel about each statement. For example:

\begin{tabular}{|c|c|c|c|c|c|}
\hline Example 1: & $\begin{array}{c}\text { Strongly } \\
\text { Disagree }\end{array}$ & Disagree & $\begin{array}{c}\text { Neither } \\
\text { Agree nor } \\
\text { Disagree }\end{array}$ & Agree & $\begin{array}{c}\text { Strongly } \\
\text { Agree }\end{array}$ \\
\hline I like engineering. & $\bigcirc$ & 0 & 0 & 0 & $\bigcirc$ \\
\hline
\end{tabular}

As you read the sentence, you will know whether you agree or disagree. Fill in the circle that describes how much you agree or disagree.

Even though some statements are very similar, please answer each statement. This is not timed; work fast, but carefully.

There are no "right" or "wrong" answers! The only correct responses are those that are true for you. Whenever possible, let the things that have happened to you help you make a choice.

Please fill in only one answer per question.

Recommended citation for this survey:

Friday Institute for Educational Innovation (2012). Middle/High School Student Attitudes toward STEM Survey. Raleigh, NC: Author. 


\begin{tabular}{|l|c|c|c|c|c|}
\hline & $\begin{array}{c}\text { Strongly } \\
\text { Disagree }\end{array}$ & Disagree & $\begin{array}{c}\text { Neither } \\
\text { Agree nor } \\
\text { Disagree }\end{array}$ & Agree & $\begin{array}{c}\text { Strongly } \\
\text { Agree }\end{array}$ \\
\hline $\begin{array}{l}\text { 27. Math has been my worst } \\
\text { subject. }\end{array}$ & 0 & 0 & 0 & 0 & 0 \\
\hline $\begin{array}{l}\text { 28. I would consider choosing a } \\
\text { career that uses math. }\end{array}$ & 0 & 0 & 0 & 0 & 0 \\
\hline $\begin{array}{l}\text { 29. Math is hard for me. } \\
\begin{array}{l}\text { 30. I am the type of student to do } \\
\text { well in math. }\end{array}\end{array}$ & 0 & 0 & 0 & 0 & 0 \\
\hline $\begin{array}{l}\text { 31. I can handle most subjects } \\
\text { well, but I cannot do a good } \\
\text { job with math. }\end{array}$ & 0 & 0 & 0 & 0 & 0 \\
\hline $\begin{array}{l}\text { 32. I am sure I could do advanced } \\
\text { work in math. }\end{array}$ & 0 & 0 & 0 & 0 & 0 \\
\hline $\begin{array}{l}\text { 33. I can get good grades in math. } \\
\text { 34. I am good at math. }\end{array}$ & 0 & 0 & 0 & 0 & 0 \\
\hline
\end{tabular}

\section{Science}

\begin{tabular}{|c|c|c|c|c|c|}
\hline & $\begin{array}{l}\text { Strongly } \\
\text { Disagree }\end{array}$ & Disagree & $\begin{array}{l}\text { Neither } \\
\text { Agree nor } \\
\text { Disagree }\end{array}$ & Agree & $\begin{array}{c}\text { Strongly } \\
\text { Agree }\end{array}$ \\
\hline $\begin{array}{l}\text { 35. I am sure of myself when I do } \\
\text { science. }\end{array}$ & 0 & 0 & 0 & 0 & 0 \\
\hline $\begin{array}{l}\text { 36. I would consider a career in } \\
\text { science. }\end{array}$ & O & 0 & O & 0 & O \\
\hline $\begin{array}{l}\text { 37. I expect to use science when I } \\
\text { get out of school. }\end{array}$ & 0 & 0 & 0 & O & 0 \\
\hline $\begin{array}{l}\text { 38. Knowing science will help } \\
\text { me earn a living. }\end{array}$ & 0 & 0 & 0 & 0 & 0 \\
\hline $\begin{array}{l}\text { 39. I will need science for my } \\
\text { future work. }\end{array}$ & 0 & 0 & 0 & 0 & 0 \\
\hline $\begin{array}{l}\text { 40. I know I can do well in } \\
\text { science. }\end{array}$ & 0 & 0 & 0 & 0 & 0 \\
\hline $\begin{array}{l}\text { 41. Science will be important to } \\
\text { me in my life's work. }\end{array}$ & 0 & 0 & 0 & 0 & 0 \\
\hline $\begin{array}{l}\text { 42. I can handle most subjects } \\
\text { well, but I cannot do a good } \\
\text { job with science. }\end{array}$ & 0 & 0 & 0 & 0 & 0 \\
\hline
\end{tabular}




\begin{tabular}{|l|c|c|c|c|c|}
\hline & $\begin{array}{c}\text { Strongly } \\
\text { Disagree }\end{array}$ & Disagree & $\begin{array}{c}\text { Neither } \\
\text { Agree nor } \\
\text { Disagree }\end{array}$ & Agree & $\begin{array}{c}\text { Strongly } \\
\text { Agree }\end{array}$ \\
\hline $\begin{array}{c}\text { 43. I am sure I could do advanced } \\
\text { work in science. }\end{array}$ & 0 & 0 & 0 & 0 & 0 \\
\hline
\end{tabular}

\section{Engineering and Technology}

Please read this paragraph before you answer the questions.

Engineers use math, science, and creativity to research and solve problems that improve everyone's life and to invent new products. There are many different types of engineering, such as chemical, electrical, computer, mechanical, civil, environmental, and biomedical. Engineers design and improve things like bridges, cars, fabrics, foods, and virtual reality amusement parks. Technologists implement the designs that engineers develop; they build, test, and maintain products and processes.

\begin{tabular}{|l|c|c|c|c|c|}
\hline & $\begin{array}{c}\text { Strongly } \\
\text { Disagree }\end{array}$ & Disagree & $\begin{array}{c}\text { Neither } \\
\text { Agree nor } \\
\text { Disagree }\end{array}$ & Agree & $\begin{array}{c}\text { Strongly } \\
\text { Agree }\end{array}$ \\
\hline $\begin{array}{l}\text { 44. I like to imagine creating new } \\
\text { products. }\end{array}$ & 0 & 0 & 0 & 0 & 0 \\
\hline $\begin{array}{l}\text { 45. If I learn engineering, then I } \\
\text { can improve things that } \\
\text { people use every day. }\end{array}$ & 0 & 0 & 0 & 0 & 0 \\
\hline $\begin{array}{l}\text { 46. I am good at building and } \\
\text { fixing things. }\end{array}$ & 0 & 0 & 0 & 0 & 0 \\
\hline $\begin{array}{l}\text { 47. I am interested in what makes } \\
\text { machines work. }\end{array}$ & 0 & 0 & 0 & 0 & 0 \\
\hline $\begin{array}{l}\text { 48. Designing products or } \\
\text { structures will be important } \\
\text { for my future work. }\end{array}$ & 0 & 0 & 0 & 0 & 0 \\
\hline $\begin{array}{l}\text { 49. I am curious about how } \\
\text { electronics work. }\end{array}$ & 0 & 0 & 0 & 0 & 0 \\
\hline $\begin{array}{l}\text { 50. I would like to use creativity } \\
\text { and innovation in my future } \\
\text { work. }\end{array}$ & 0 & 0 & 0 & 0 & 0 \\
\hline $\begin{array}{l}\text { 51. Knowing how to use math } \\
\text { and science together will } \\
\text { allow me to invent useful } \\
\text { things. }\end{array}$ & 0 & 0 & 0 & 0 & 0 \\
\hline $\begin{array}{l}\text { 52. I believe I can be successful } \\
\text { in a career in engineering. }\end{array}$ & 0 & 0 & $\bigcirc$ & 0 & 0 \\
\hline
\end{tabular}




\section{$21^{\text {st }}$ Century Skills}

\begin{tabular}{|c|c|c|c|c|c|}
\hline & $\begin{array}{l}\text { Strongly } \\
\text { Disagree }\end{array}$ & Disagree & $\begin{array}{l}\text { Neither } \\
\text { Agree nor } \\
\text { Disagree }\end{array}$ & Agree & $\begin{array}{c}\text { Strongly } \\
\text { Agree }\end{array}$ \\
\hline $\begin{array}{l}\text { 38. I am confident I can lead } \\
\text { others to accomplish a goal. }\end{array}$ & 0 & 0 & 0 & 0 & 0 \\
\hline $\begin{array}{l}\text { 39. I am confident I can encourage } \\
\text { others to do their best. }\end{array}$ & 0 & 0 & 0 & O & 0 \\
\hline $\begin{array}{l}\text { 40. I am confident I can produce } \\
\text { high quality work. }\end{array}$ & 0 & 0 & 0 & 0 & 0 \\
\hline $\begin{array}{l}\text { 41. I am confident I can respect the } \\
\text { differences of my peers. }\end{array}$ & 0 & 0 & 0 & 0 & 0 \\
\hline $\begin{array}{l}\text { 42. I am confident I can help my } \\
\text { peers. }\end{array}$ & 0 & 0 & 0 & 0 & 0 \\
\hline $\begin{array}{l}\text { 43. I am confident I can include } \\
\text { others' perspectives when } \\
\text { making decisions. }\end{array}$ & 0 & 0 & O & 0 & 0 \\
\hline $\begin{array}{l}\text { 44. I am confident I can make } \\
\text { changes when things do not go } \\
\text { as planned. }\end{array}$ & 0 & 0 & 0 & 0 & 0 \\
\hline $\begin{array}{l}\text { 45. I am confident I can set my } \\
\text { own learning goals. }\end{array}$ & 0 & 0 & 0 & 0 & 0 \\
\hline $\begin{array}{l}\text { 46. I am confident I can manage } \\
\text { my time wisely when working } \\
\text { on my own. }\end{array}$ & 0 & 0 & 0 & 0 & 0 \\
\hline $\begin{array}{l}\text { 47. When I have many } \\
\text { assignments, I can choose } \\
\text { which ones need to be done } \\
\text { first. }\end{array}$ & 0 & 0 & 0 & 0 & 0 \\
\hline $\begin{array}{l}\text { 48. I am confident I can work well } \\
\text { with students from different } \\
\text { backgrounds. }\end{array}$ & 0 & 0 & O & 0 & 0 \\
\hline
\end{tabular}

\section{Your Future}

Here are descriptions of subject areas that involve math, science, engineering and/or technology, and lists of jobs connected to each subject area. As you read the list below, you will know how interested you are in the subject and the jobs. Fill in the circle that relates to how interested you are.

There are no "right" or "wrong" answers. The only correct responses are those that are true for you. 


\begin{tabular}{|c|c|c|c|c|}
\hline & $\begin{array}{l}\text { Not at all } \\
\text { Interested }\end{array}$ & $\begin{array}{c}\text { Not So } \\
\text { Interested }\end{array}$ & Interested & $\begin{array}{c}\text { Very } \\
\text { Interested }\end{array}$ \\
\hline $\begin{array}{l}\text { 13. Physics: is the study of basic laws } \\
\text { governing the motion, energy, } \\
\text { structure, and interactions of matter. } \\
\text { This can include studying the nature of } \\
\text { the universe. (aviation engineer, } \\
\text { alternative energy technician, lab } \\
\text { technician, physicist, astronomer) }\end{array}$ & 0 & 0 & O & 0 \\
\hline $\begin{array}{l}\text { 14. Environmental Work: involves } \\
\text { learning about physical and biological } \\
\text { processes that govern nature and } \\
\text { working to improve the environment. } \\
\text { This includes finding and designing } \\
\text { solutions to problems like pollution, } \\
\text { reusing waste and recycling. (pollution } \\
\text { control analyst, environmental } \\
\text { engineer or scientist, erosion control } \\
\text { specialist, energy systems engineer and } \\
\text { maintenance technician) }\end{array}$ & 0 & 0 & 0 & 0 \\
\hline $\begin{array}{l}\text { 15. Biology and Zoology: involve the } \\
\text { study of living organisms (such as } \\
\text { plants and animals) and the processes } \\
\text { of life. This includes working with } \\
\text { farm animals and in areas like nutrition } \\
\text { and breeding. (biological technician, } \\
\text { biological scientist, plant breeder, crop } \\
\text { lab technician, animal scientist, } \\
\text { geneticist, zoologist) }\end{array}$ & 0 & 0 & 0 & 0 \\
\hline $\begin{array}{l}\text { 16. Veterinary Work: involves the } \\
\text { science of preventing or treating } \\
\text { disease in animals. (veterinary } \\
\text { assistant, veterinarian, livestock } \\
\text { producer, animal caretaker) }\end{array}$ & 0 & 0 & 0 & 0 \\
\hline $\begin{array}{l}\text { 17. Mathematics: is the science of } \\
\text { numbers and their operations. It } \\
\text { involves computation, algorithms and } \\
\text { theory used to solve problems and } \\
\text { summarize data. (accountant, applied } \\
\text { mathematician, economist, financial } \\
\text { analyst, mathematician, statistician, } \\
\text { market researcher, stock market } \\
\text { analyst) }\end{array}$ & 0 & 0 & 0 & 0 \\
\hline
\end{tabular}




\begin{tabular}{|l|c|c|c|c|}
\hline & $\begin{array}{c}\text { Not at all } \\
\text { Interested }\end{array}$ & $\begin{array}{c}\text { Not So } \\
\text { Interested }\end{array}$ & Interested & $\begin{array}{c}\text { Very } \\
\text { Interested }\end{array}$ \\
\hline $\begin{array}{l}\text { 18. Medicine: involves maintaining health } \\
\text { and preventing and treating disease. } \\
\text { (physician's assistant, nurse, doctor, } \\
\text { nutritionist, emergency medical } \\
\text { technician, physical therapist, dentist) }\end{array}$ & 0 & 0 & 0 & 0 \\
\hline $\begin{array}{l}\text { 19. Earth Science: is the study of earth, } \\
\text { including the air, land, and ocean. } \\
\text { (geologist, weather forecaster, }\end{array}$ & 0 & 0 & 0 & 0 \\
$\begin{array}{l}\text { archaeologist, geoscientist) } \\
\text { 20. Computer Science: consists of the } \\
\text { development and testing of computer } \\
\text { systems, designing new programs and } \\
\text { helping others to use computers. } \\
\text { (computer support specialist, computer } \\
\text { programmer, computer and network } \\
\text { technician, gaming designer, computer } \\
\text { software engineer, information } \\
\text { technology specialist) }\end{array}$ & 0 & 0 & 0 & 0 \\
\hline $\begin{array}{l}\text { 21. Medical Science: involves researching } \\
\text { human disease and working to find new } \\
\text { solutions to human health problems. } \\
\text { (clinical laboratory technologist, } \\
\text { medical scientist, biomedical engineer, } \\
\text { epidemiologist, pharmacologist) }\end{array}$ & 0 & 0 & 0 & 0 \\
\hline $\begin{array}{l}\text { 22. Chemistry: uses math and experiments } \\
\text { to search for new chemicals, and to } \\
\text { study the structure of matter and how it } \\
\text { behaves. (chemical technician, chemist, } \\
\text { chemical engineer) }\end{array}$ & 0 & 0 & 0 & 0 \\
\hline $\begin{array}{l}\text { 23. Energy: involves the study and } \\
\text { generation of power, such as heat or } \\
\text { electricity. (electrician, electrical } \\
\text { engineer, heating, ventilation, and air } \\
\text { conditioning (HVAC) technician, } \\
\text { nuclear engineer, systems engineer, } \\
\text { alternative energy systems installer or } \\
\text { technician) }\end{array}$ & 0 & & & \\
\hline
\end{tabular}




\begin{tabular}{|l|c|c|c|c|}
\hline $\begin{array}{l}\text { 24. Engineering: involves designing, } \\
\text { testing, and manufacturing new } \\
\text { products (like machines, bridges, } \\
\text { buildings, and electronics) through the } \\
\text { use of math, science, and computers. } \\
\text { (civil, } \text { industrial, agricultural, } \text { or } \\
\text { mechanical } \text { engineers, } \text { welder, auto- } \\
\text { mechanic, } \text { engineering technician, } \\
\text { construction manager) }\end{array}$ & 0 & $\begin{array}{c}\text { Not So } \\
\text { Interested }\end{array}$ & Interested & $\begin{array}{c}\text { Very } \\
\text { Interested }\end{array}$ \\
\hline
\end{tabular}

\section{About Yourself}

1. How well do you expect to do this year in your:

\begin{tabular}{|l|c|c|c|}
\hline & Not Very Well & OK/Pretty Well & Very Well \\
\hline English/Language Arts Class? & $\bigcirc$ & $\bigcirc$ & $\bigcirc$ \\
\hline Math Class? & $\bigcirc$ & $\bigcirc$ & $\bigcirc$ \\
\hline Science Class? & $\bigcirc$ & $\bigcirc$ & $\bigcirc$ \\
\hline
\end{tabular}

2. In the future, do you plan to take advanced classes in:

\begin{tabular}{|l|c|c|c|}
\hline & Yes & No & Not Sure \\
\hline Mathematics? & $\bigcirc$ & $\bigcirc$ & $\bigcirc$ \\
\hline Science? & $\bigcirc$ & $\bigcirc$ & 0 \\
\hline
\end{tabular}

3. Do you plan to go to college?

$\mathrm{O}$ Yes

O No

O Not Sure

4. More about you.

\begin{tabular}{|l|c|c|c|}
\hline & Yes & No & Not Sure \\
\hline Do you know any adults who work as scientists? & $\bigcirc$ & $\bigcirc$ & $\bigcirc$ \\
\hline Do you know any adults who work as engineers? & $\bigcirc$ & $\bigcirc$ & $\bigcirc$ \\
\hline Do you know any adults who work as mathematicians? & $\bigcirc$ & $\bigcirc$ & $\bigcirc$ \\
\hline Do you know any adults who work as technologists? & $\bigcirc$ & $\bigcirc$ & $\bigcirc$ \\
\hline
\end{tabular}

